\title{
Does Intended Use Influence the Initial Returns of Initial Public Offering (IPO) Amidst Economic Crisis of Covid-19
}

Siti Azrina Adanan, Khair Syakira Bustamam, Khairunnisa Abd Samad, A'ieshah Abdullah Sani, Amilia Saidin \& Siti Nurulhuda Mamat

To Link this Article: http://dx.doi.org/10.6007/IJARAFMS/v11-i3/11209 DOI:10.6007/IJARAFMS /v11-i3/11209

Received: 21 July 2021, Revised: 10 August 2021, Accepted: 29 August 2021

Published Online: 23 September 2021

In-Text Citation: (Adanan et al., 2021)

To Cite this Article: Adanan, S. A., Bustamam, K. S., Samad, K. A., Sani, A. A., Saidin, A., \& Mamat, S. N. (2021). Does Intended Use Influence the Initial Returns of Initial Public Offering (IPO) Amidst Economic Crisis of Covid-19. International Journal of Academic Research in Accounting Finance and Management Sciences, 11(13), 629-643.

Copyright: (c) 2021 The Author(s)

Published by Human Resource Management Academic Research Society (www.hrmars.com)

This article is published under the Creative Commons Attribution (CC BY 4.0) license. Anyone may reproduce, distribute, translate and create derivative works of this article (for both commercial and non-commercial purposes), subject to full attribution to the original publication and authors. The full terms of this license may be seen

at: http://creativecommons.org/licences/by/4.0/legalcode

Vol. 11, No. 3, 2021, Pg. 629 - 643

Full Terms \& Conditions of access and use can be found at http://hrmars.com/index.php/pages/detail/publication-ethics 


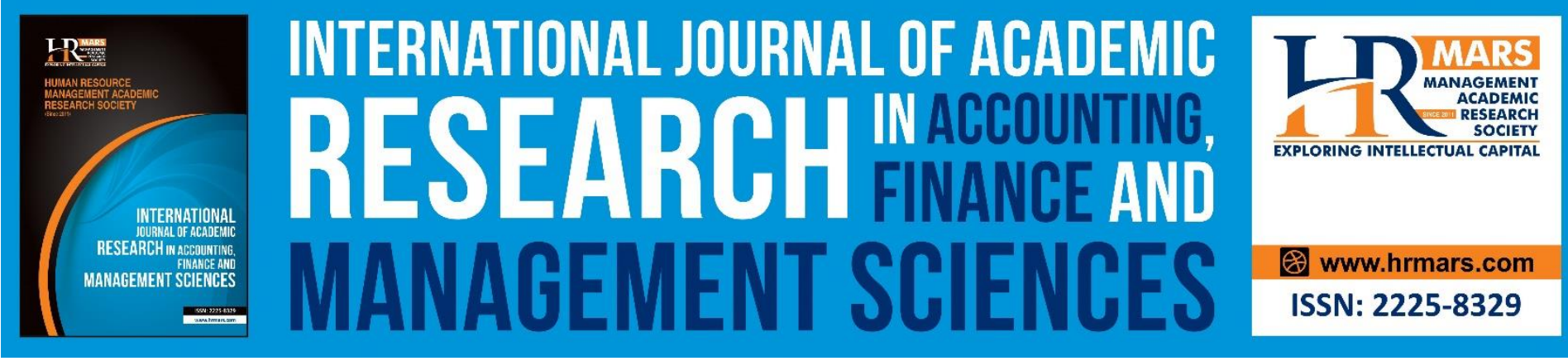

\title{
Does Intended Use Influence the Initial Returns of Initial Public Offering (IPO) Amidst Economic Crisis of Covid-19
}

\author{
Siti Azrina Adanan, Khair Syakira Bustamam, Khairunnisa Abd \\ Samad, A'ieshah Abdullah Sani, Amilia Saidin \& Siti Nurulhuda \\ Mamat \\ Faculty of Accountancy, Universiti Teknologi MARA, KM26, Jalan Lendu, 78000 Alor Gajah \\ Melaka \\ Email:azrina@uitm.edu.my
}

\begin{abstract}
The Covid-19 consequences on stock market performance has important implications to global economic and businesses financial performance. It is crucial for companies to make wise economic and strategic decision amid the situation to diverse and expand their business for sustainability. Initial Public Offering (IPO) provides an avenue for the companies to raise capital for those purposes. This study analysed the performance of Initial IPO initial returns during the Movement Control Order (MCO) in Malaysia. We extended the study to explore the relationship between issuance proceeds intended use (investment and growth, working capital and debt repayment) and initial IPO performance. Data were collected from prospectus, firms' websites, and DataStream Database involving 65 IPO companies since 2016. Using pairwise correlation and OLS regression, we found that despite less IPO being issued during the MCO, a significant number of the IPO issued reported positive initial return (under-pricing). The result also reported significant negative initial return for investment and growth as well as debt repayment intended use. Our findings contribute to the further discussion on corporate financing plans and investment strategies for investors. It also provides opportunity for further research to explore the post operating performance of IPO issued amidst economic crisis of Covid-19.
\end{abstract}

Keywords: IPO Proceeds, Intended Use, Under-pricing, Initial Performance, Market Reaction

\section{Introduction}

Firms raise external capital for various purposes. Initial Public Offerings (IPO) is one method of raising external capital among corporations other than debt financing. IPO enables firms to raise capital for various corporations' purposes. Despite the global health crisis which leads to domestic and global financial uncertainties, IPO remains as a key source of financing to improve corporate standing. The pandemic has resulted in a significant economic meltdown throughout the world. In Malaysia, in response to the World Health Organization (WHO) recommendation, the government has first declared a Movement Control Order (MCO) since 
MANAGEMENT SCIENCES

Vol. 11, No. 3, 2021, E-ISSN: 2225-8329 ๔ 2021 HRMARS

18 March 2020, followed by a conditional MCO, and recovery MCO. Since then, the pandemic situation has shown no signal of diminishing. The second, third and fourth wave of pandemic that hit Malaysia caused a stop to the economic and social activities. Other than the essential economic sectors, other sectors are not allowed to operate at all, and fears grow among investors as the crisis may cause economic damage and this would affect their investment decision.

For the Malaysian equity market, 2020 was a challenging year for market participants including investors and issuing companies. This health shock pandemic created a panic reaction among investors where they prefer to hold cash rather than stock portfolios and exit the market. In relation to the IPO market, disruptions caused by the Covid- 19 pandemic in 2020 witnessed only 19 new listings in three Bursa Malaysia markets as compared to 30 new firms listed in the market in 2019. However, from January 2020 until March 2021, most of the initial performance of IPO in the local market shows strong performance with a huge premium over their offer price (under-priced). The IPO debut increased confidence among issuing firms and potential investors to participate in the IPO issuance. To support this, the Securities Commission Malaysia (SC) is expecting more companies to debut on Bursa Malaysia despite the fear of Covid-19 uncertainties.

Various studies were conducted to support the hypothesis that the pandemic has a relationship with investment returns. Using the fear of Covid-19 index, Mazumder \& Saha (2021) reported the prevalence of high fear in the market is associated with decrease of adjusted initial return and concluded that the index had a negative relationship with IPOs' initial returns. The fear affected newer firms more than older firms. A study conducted in Indonesia reported that the under-pricing phenomenon still occurred during the pandemic period (Kuswanto, 2021). It shows that, despite the pandemic fear, investors can still have a feasible return for IPO investment. Overall, Bhat \& Suresh (2020) agreed that stock return among investors from trading activities was also affected during the pandemic. The contradict IPO initial return between empirical findings provides an avenue for researchers to investigate further the factors that would contribute to such reactions.

The main purpose of this paper is to investigate empirically whether information on the intended use of IPO proceeds has an impact on IPO initial return especially during the pandemic. In relation to IPO issuance, the Bursa Malaysia Listing Requirement imposed rules for capital market participants to operates under a disclosure-based regime whereby the potential investors have the right to adequate information on all main aspects of the business to make an informed investment decision. Thus, the Security Commission of Malaysia has issued guidelines on prospectus disclosure which also include intended use of proceeds of an IPO. However, there are no guidelines or rules on the proceed allocation proportion as the issuing companies may use all the proceeds to meet their own financial needs despite mandatory disclosure of this information. Apart from information on the intended use of proceeds, evidence also supported that the firms' sector in which they are operate and whether they are a Shariah compliance operating firm or not also has an impact on initial return. Technology sectors tend to show positive IPO return (Leone \& Willenborg, 2007; Chung et al., 2005; Beatty \& Ritter, 1986) whereas Abdul Rahim and Yong (2010) managed to relate Shariah status of the firm with under-pricing on the debut day. 
MANAGEMENT SCIENCES

Vol. 11, No. 3, 2021, E-ISSN: 2225-8329 ๔ 2021 HRMARS

Extensive research has been conducted in investigating the intended proceed use with IPO and other firms' performance. Different categories are applied to subdivide the intended use of proceeds based on their sample sources and main categories highlighted by the Securities Exchange Commission (SEC). A study of Indonesian Stock exchange by Andriansyah \& Messinis (2016) classified the intended use into five categories: fixed assets investment, working capital financing, investment in stocks, debt repayments and secondary shares ${ }^{1}$. Research conducted by Amor \& Kooli (2016) categorised intended use of proceeds into four categories: investment, debt repayment, marketing $\&$ sales promotion, and general corporate purposes ${ }^{2}$. Autore et al. (2009) only stated three main categories: investment, recapitalization, and general corporate purposes. This study uses categories adopted by Ahmad-Zaluki \& Badru (2020) which grouped the intended uses of IPO proceeds into growth opportunities ${ }^{3}$, debt repayment and working capital as these intended uses are most common among IPOs in Malaysia and can minimize zero values in the analysis. We expand the research conducted by Ahmad-Zaluki \& Badru (2020) by investigating the initial return of IPOs during pandemic to provide knowledge on how investors react on IPO in the period of uncertainties. Thus, the research questions addressed are:

1. Does the Covid-19 pandemic have an implication on IPOs' initial return?

2. Does the intended use of proceeds have implications on IPOs' initial return?

The rest of the paper discusses the following: Section 2 explores the literature reviews and hypothesis development; Section 3 discusses the sample data and research method; Section 4 elaborates on the discussion of the results; and Section 5 concludes the paper.

\section{Literature Review \\ IPO Under-pricing}

IPO under-pricing is a common phenomenon in Malaysia and other countries' equity markets. Prior theoretical and empirical evidence indicates a significant and high positive initial return of the IPO on its debut day. It is important to identify the contributing factors that lead to this common event. Studies in various markets have been conducted to investigate the determinants of positive initial returns of IPO.

In the case of the Malaysian market, Ahmad-Zaluki \& Badru (2020) reported a significant positive initial return at 1 percent and Abdul Rahim \& Yong (2010) documented a positive initial return for their studies on IPO issued from 1999 to 2017. In addition to that, Ammer \& Ahmad-Zaluki (2016) also reported IPO under-pricing by investigating it in relation to underwriter's market share and spread, biases and accuracy of the earnings forecasts. A study conducted by Yazdani \& Aris (2015) confirmed that IPOs are mostly under-priced in the short term (9.4 percent). The study suggested that multiple factors can contribute to under-pricing which include the size of the IPO, volatility of market, status of the underwriter and IPO offer price.

\footnotetext{
${ }^{1}$ Secondary shares in the study refers to the total proceeds percentage from secondary shares that was intended to be sold by initial owners.

${ }^{2}$ Investment use includes acquisition, Research and Development (R\&D), and capital expenditure (CAPEX).

${ }^{3}$ Growth opportunity categories include capital expenditure and Research and Development as such expenditure main objectives is to promote growth.
} 
MANAGEMENT SCIENCES

Vol. 11, No. 3, 2021, E-ISSN: 2225-8329 @ 2021 HRMARS

Another study conducted in emerging markets also reported the same under-pricing phenomenon. Rathnayake et al (2019) found that on average, the IPOs were under-priced by 47 percent. There are various factors identified to have significant relationship with IPO under-pricing i.e., investor sentiment, firm size and age, market volatility, and period of issuance. In addition to this, Gao \& Hou (2019) also investigated the first-day under-pricing of 142 IPOs in Taiwan during the post-financial crisis period of 2009 to 2011 and the result showed a substantial IPO under-pricing of approximately 30.26 percent.

During the pandemic of Covid-19, recent studies that investigate the pandemic implication on IPO initial performance showed significant relationship (Bhat \& Suresh, 2020; Kuswanto 2021; Mazumder \& Saha 2021) ${ }^{4}$. This study thus hypothesized that the MCO imposed by the Malaysian government during the pandemic has a relationship with initial return.

\section{H1: The Covid-19 pandemic has relationship on initial returns}

\section{Intended Use of Proceed and IPO Performance}

In general, IPO companies highlight their valuable investment options in the prospectus by disclosing their intended use of proceeds. Investors use this data to make assumptions about the company's risks and prospects, as also as those of competitors (McGilvery et al., 2012).

Studies on asymmetric information and its influence on early returns are critical because when a business goes public, there is uncertainty owing to asymmetric knowledge amongst all stakeholders, including issuers, investors, and underwriters (Siew \& Sundarasen, 2015). Empirical findings have shown that IPOs generate positive initial returns on the first trading day (Ahmad-Zaluki \& Badru, 2020; Abdul Rahman \& Che-Yahya 2019; Gao \& Hou, 2019). This occurs when the closing price of a company's stock on the first trading day is significantly higher than the offer price set before the IPO. These phenomena can be explained using theoretical information asymmetry (leading to ex-ante uncertainty ${ }^{5}$ ), which means that parties participating in the IPO process, have limited information causing them reluctant to participate in the market. Thus, the disclosure of an IPO's intended use of proceeds in the prospectus is a better predictor of ex-ante uncertainty about the IPO's value (Beatty \& Ritter, 1986). This information is vital to seek the relationship between intended use of proceed and the first day initial return which generally exhibit positive initial return on the debut date.

The motive of the IPO companies varies accordingly. According to Ahmad-Zaluki \& Badru (2020), IPO companies in Malaysia allocate around 48.48 percent of their IPO proceeds for growth opportunities purposes, 26.34 percent for working capital purposes and 13.04 percent for debt repayment purposes. In contrast to Bangladesh capital market, Rahman et al (2021) further elaborate that debt repayment was the primary motivation for using IPO proceeds, followed by growth opportunities, working capital finance and floatation costs accounted for approximately 6 percent of overall IPO proceeds.

\footnotetext{
${ }^{4}$ Bhat \& Suresh (2020) reported negative initial return, Kuswanto (2021) reported positive initial return and Mazumder \& Saha (2021) reported initial return decrease as the fear to COvid-19 increases.

${ }^{5}$ ex-ante uncertainty refers to prediction of various indicators, economic and financial, by evaluating past and present data and parameters
} 
From Malaysian capital market context, Ahmad-Zaluki \& Badru (2020) found that the use of proceeds for working capital and growth opportunities is positively associated with IPO initial returns. In a study conducted from January 2000 through December 2014 on 403 IPOs companies, Abdul Rahman \& Che-Yahya (2019) also discovered a positive association between growth opportunities and IPOs' performance. The positive relationship is consistent with Chung et al (2005) as opposed to the study conducted in the American Stock Exchange for the period from 1996 to 2001. Chung et al (2005) further discovered that the average initial return is 42.58 percent with a significant positive relation with growth premium and initial return. As such, the chances of IPO companies having less profit in the long term are lower with a higher share assigned to growth and investment activities. In return, a positive IPO of the companies will not only take place during the initial return but also in the long term (Amor \& Kooli, 2016).

According to Leone et al (2007), debt repayment and R\&D are adversely related with IPO early returns, suggesting that investors feel information on the use of proceeds for debt repayment offers further insights for investment decisions. This further elaborates that debt repayment is not regarded a signal of projected cash flows and may be a negative indicator of future investment possibilities, potentially jeopardising IPO subscription and flattening future profits streams (McGuinness, 2019).

Based on the above evidence and in accordance with the ex-uncertainty hypothesis, the present study hypothesizes that the intended use of the IPO proceeds may provide a better explanation for the IPO initial returns.

\section{H2: Intended use has relationship on initial returns}

\section{Firms' Sector and Shariah Compliance Status Influence on IPO Performance}

High-tech ${ }^{6}$ companies often use an IPO to raise capital as they tend to be more volatile than non-technology companies. Most high-tech companies possess more intangible assets such as patents, trademarks and such asset structures are exposed to financing risk if high-tech companies employ debt financing (Gao \& Hou, 2019). Previous empirical research described that the initial returns are higher for IPO companies in high-tech industries (Leone et al. 2007; Chung et al. 2005; Beatty \& Ritter 1986). According to Baig \& Chen (2021), following the COVID-19, businesses in the high-tech industry face more under-pricing and post-IPO volatility. However, Ahmad-Zaluki \& Badru (2020) opposed the previous research findings and found that the high-tech industry had a negative but substantial correlation with IPO early returns. The negative indication indicates that IPOs are less likely to be associated with high level of uncertainty. As a result, the assumption that technology IPOs are characterised by a significant degree of uncertainty may not apply to Malaysian IPOs which is opposed to study by Ahmad-Zaluki \& Kect (2012) on the Malaysian IPO market.

Based on empirical information from the Malaysian capital market conducted after the 1997 financial crisis, the link between initial return and Shariah compliant status IPO is scarcely

\footnotetext{
${ }^{6}$ high-tech companies refers to 'industries' registered by the listed companies in Bursa Malaysia Kuala Lumpur. Most of them registered under ACE market (formerly known as MESDAQ market prior to 3rd August 2009).
} 
MANAGEMENT SCIENCES

Vol. 11, No. 3, 2021, E-ISSN: 2225-8329 @ 2021 HRMARS

discernible. Abdul Rahim \& Yong (2008); Abdul Rahim \& Che Embi (2013) and Abdul Rahim \& Yong (2010) found a link between Shariah compliance and market under-pricing. The results depicted that issuing Shariah-compliant securities enabled the issuer to obtain funds more easily and the shares could be sold to a bigger group of investors. However, based on previous studies, Shariah-compliant status was revealed to have a positive relevance on one of the determinants of IPO, oversubscription. This suggests that Shariah-compliant status attracts investors to IPO subscription since share distribution can be done to a bigger set of investors (Tajuddin et al., 2019). However, according to a study conducted in the Pakistan capital market, non-Shariah compliant IPOs are more under-priced than Shariah compliant firms on the first day of debut. It is recommended that Shariah IPOs in Pakistan operate under stricter standards and with greater transparency, resulting in lower risk and uncertainty, which may minimise the degree of IPO under-pricing (Mehmood et al., 2021). The previous empirical findings on the technology sector and Shariah compliance status in influencing the IPO initial returns provide avenue for this study to hypothesises that both variables have implication on initial returns of the IPO.

\section{H3: Technology sector firms IPO positively related to the initial returns}

H4: Shariah compliant firms IPO positively related to initial returns

\section{Methodology}

\section{Sample and Data}

All 117 IPO companies listed on Bursa Malaysia from January 2016 to March 2021 are considered as an initial sample. The sample of this study consists of 65 IPO companies after excluding Real Estate Investment Trusts (REITs), Special Purpose Acquisition Companies (SPACs) and close-ended fund IPOs because of different regulatory requirements for such IPOs (Ammer \& Ahmad-Zaluki 2016; Abdul Rahim \& Yong, 2010; Badru et al., 2018). Leap market IPO is also excluded from the sample because it is governed by different acts and only accessible by sophisticated investors. This final sample represents 69 percent of the total IPOs listed between January 2016 to March 2021.

Data for the total of IPO proceeds and its percentage of intended use were mainly extracted from prospectus and firms' websites. Other data that represent variables for this research paper such as offer price and firms' sector are also derived from the same source. The intended use of IPO proceeds is categorised into three categories, namely, investment for growth opportunity (CAPEX and R\&D), working capital, and debt repayment. The closing price of the IPOs on their first day trading day were obtained from DataStream Database.

\section{Method}

The study aims to investigate the relationship between intended use of proceeds and initial return on stock. The study employs cross sections of 65 companies listed as IPO since January 2016. The study also tested for the significance initial return of hi-tech companies by using the $t$-test relationship. For the regression analysis, the study uses pairwise correlation and static panel estimation methods.

In deriving the IPO initial performance, the unadjusted initial returns are used (Ahmad-Zaluki \& Badru, 2020). The unadjusted initial returns of IPOs that issued within the time frame from January 2016 to March 2021 are used as the dependent variable, which are estimated as follows: 


$$
\begin{aligned}
\text { IRCLOSi; } t= & \frac{\mathrm{Pi}, \mathrm{t}-\mathrm{Pi}, 0}{\mathrm{Pi}, 0}
\end{aligned}
$$

where IRCLOSi; $t$ is the initial returns (INIRTN) for company i on the first day of trading ; $\mathrm{Pi}, \mathrm{t}$ is the closing price of company $i$ at the end of the first day of listing; $\mathrm{Pi}, 0$ is the offer price of company $i$ at the time of issue. The average initial returns are calculated from the gap between the IPO offer price (as stated in the prospectus) and the closing price on the first day of listing.

\section{Findings and Discussion}

Descriptive Analysis

Table 1: Data Description

\begin{tabular}{|c|c|c|}
\hline Variable & Definition & Source \\
\hline INIRTN & $\begin{array}{l}\text { Percentage of difference between offer and closing price } \\
\text { of the IPO on the first listing day }\end{array}$ & $\begin{array}{l}\text { Prospectus and } \\
\text { DataStream }\end{array}$ \\
\hline PREINV & $\begin{array}{l}\text { Intended use of IPO proceed for research and } \\
\text { development purpose }\end{array}$ & Prospectus \\
\hline CAPEX & $\begin{array}{l}\text { Intended use of IPO proceed for asset acquisition and } \\
\text { other investment expenditure purpose }\end{array}$ & Prospectus \\
\hline INVGR & Total PREINV and CAPEX & Prospectus \\
\hline WCAP & $\begin{array}{l}\text { Intended use of IPO proceed for working capital financing } \\
\text { purpose }\end{array}$ & Prospectus \\
\hline DEBTRPYN & $\begin{array}{l}\text { Intended use of IPO proceed for asset debt payment } \\
\text { purpose }\end{array}$ & Prospectus \\
\hline MCO & Movement Control Order & $\begin{array}{l}\text { Public } \\
\text { announcement }\end{array}$ \\
\hline HTECH & Sectors which the firms registered in Bursa Malaysia & $\begin{array}{l}\text { Bursa Malaysia } \\
\text { website }\end{array}$ \\
\hline SHARH & $\begin{array}{l}\text { Companies which their operation and investment } \\
\text { governed by the tenets of Shariah and principles of the } \\
\text { Muslim religion. }\end{array}$ & $\begin{array}{l}\text { Bursa Malaysia } \\
\text { website }\end{array}$ \\
\hline
\end{tabular}

This table provides a detailed data description of all variables considered in this study.

Table 2: Numbers of IPOs classified by sectors and MCO

\begin{tabular}{lll}
\hline Sector & $\begin{array}{l}\text { Before MCO } \\
\text { (Jan 2016-Feb 2020) }\end{array}$ & $\begin{array}{l}\text { During MCO } \\
\text { (Mac 2020-Mac 2021) }\end{array}$ \\
\hline $\begin{array}{l}\text { Consumer } \\
\text { Industrial product \& }\end{array}$ & 12 & 2 \\
services & 17 & 7 \\
Construction & 5 & 2 \\
Technology (Hi-Tech) & 7 & 0 \\
Others (health etc) & 9 & 4 \\
Shariah & & 10 \\
Non - Shariah & 7 & 5
\end{tabular}


MANAGEMENT SCIENCES

Vol. 11, No. 3, 2021, E-ISSN: 2225-8329 @ 2021 HRMARS

We begin by discussing the summary of our data presented in Table 2. This table presents the final sample size that would be the base for inferential statistics. The entire sampled IPOs examined comprised of 65 IPOs listed from 2016-2021. The 65 IPO companies are divided into five sectors and Industrial Product \& Service sector constitutes the largest number of companies in the sample with 24 IPOs, which represent 37 percent of the sample while the lowest are from Construction and Technology sector (11 percent). There was a slowdown in the number of IPOs in all sectors during the pandemic period as all industries are seriously affected by the lockdown measure. This is concurrent with study by Baig \& Chen (2021) that reported the IPO market could have impacted badly during Covid-19 due to information uncertainty. From the final sample of 65 companies, 53 companies are Shariah-compliant IPOs while another 12 are conventional IPOs. The notable numbers of IPOs with Shariahcompliant status implied that more IPOs foresee the importance of the status before companies going public. There is high in demand for such IPOs as it attracts more investors from the Islamic countries and those investors who demand for a greater ethical type of investment (Yaakub \& Sherif, 2019).

In Table 3., specifically, we report Mean, Standard Deviation (SD), minimum (Min), and maximum (Max) values of each of the variables used in this paper. The mean, minimum and maximum value were shown in Table 3 . The data consist of 65 companies with the highest initial returns is RM1.413 and the lowest is -RM0.429. All 65 companies had their proceeds intended for the investment in the company's growth. On average all companies allocate about 49 percent of the intended proceeds in investment growth. The highest reported was about 98 percent investment allocation and reported negative initial return (overpriced). About 36 companies had their proceeds for debt repayment. Whereby 2 companies reported more than 82 percent intended proceeds allocated to debt repayment and the balance to listing fees. During MCO since March 2020, only 15 companies had initial public offerings showing a good indicator for primary market growth in Malaysia during MCO period. It shows a positive investment sentiment in general. According to Baig \& Chen (2021), pandemic indices are positively related with information uncertainty as such IPOs after the pandemic declaration experienced significantly greater under-pricing. Throughout the samples, 7 out of 65 companies are in the hi-tech industry. No IPOs in high-tech companies issued during the MCO period. This could be issuing stocks in the high-tech industry that are more volatile and the outcome is uncertain (Baig \& Chen, 2021).

Table 3: Descriptive Statistics

\begin{tabular}{llllll}
\hline Variable & Obs & Mean & Std. Dev. & Min & Max \\
\hline INIRTN & 65 & .306 & .417 & -.429 & 1.413 \\
PREINV & 39 & .365 & .248 & .015 & .937 \\
CAPEX & 48 & .385 & .228 & .037 & .803 \\
INVGR & 65 & .503 & .221 & 0 & .974 \\
WCAP & 58 & 28.293 & 16.072 & 1 & 56 \\
DEBTRPYN & 36 & .273 & .204 & .052 & .916
\end{tabular}

We conducted pairwise correlation as an overview of the relationship as depicted in Table 4. The INVGR is the summation of PREINV and CAPEX (including R\&D). The correlation between INVGR and initial returns is negative and significant. Surprisingly, it is contrary to the theoretical foundation. So, we try to understand by scattering the plot of these two variables as depicted in Figure 1. The plot shown was in inverse direction proposed a confirmation to 
MANAGEMENT SCIENCES

Vol. 11, No. 3, 2021, E-ISSN: 2225-8329 @ 2021 HRMARS

the former correlation. On the other hand, the initial returns are positively correlated with hitech companies' initial performance during the study period.

Table 4: Pairwise correlations

\begin{tabular}{lllllll}
\hline Variables & $(1)$ & $(2)$ & $(3)$ & $(4)$ & $(5)$ & $(6)$ \\
\hline (1) INIRTN & 1.000 & & & & & \\
(2) INVGR & $-0.229^{*}$ & 1.000 & & & & \\
(3) WCAP & 0.100 & $-0.343^{* *}$ & 1.000 & & & \\
(4) DEBTRPYN & 0.032 & $-0.653^{* * *}$ & $-0.335^{* * *}$ & 1.000 & & \\
(5) MCO & $0.389^{* * *}$ & -0.195 & 0.016 & 0.128 & 1.000 & \\
(6) HTECH & $0.294^{*}$ & -0.050 & -0.088 & 0.077 & -0.182 & 1.000 \\
\hline
\end{tabular}

$t$ statistics in parentheses of confidence level ${ }^{*} p<0.10,{ }^{* *} p<0.05, * * * p<0.01$

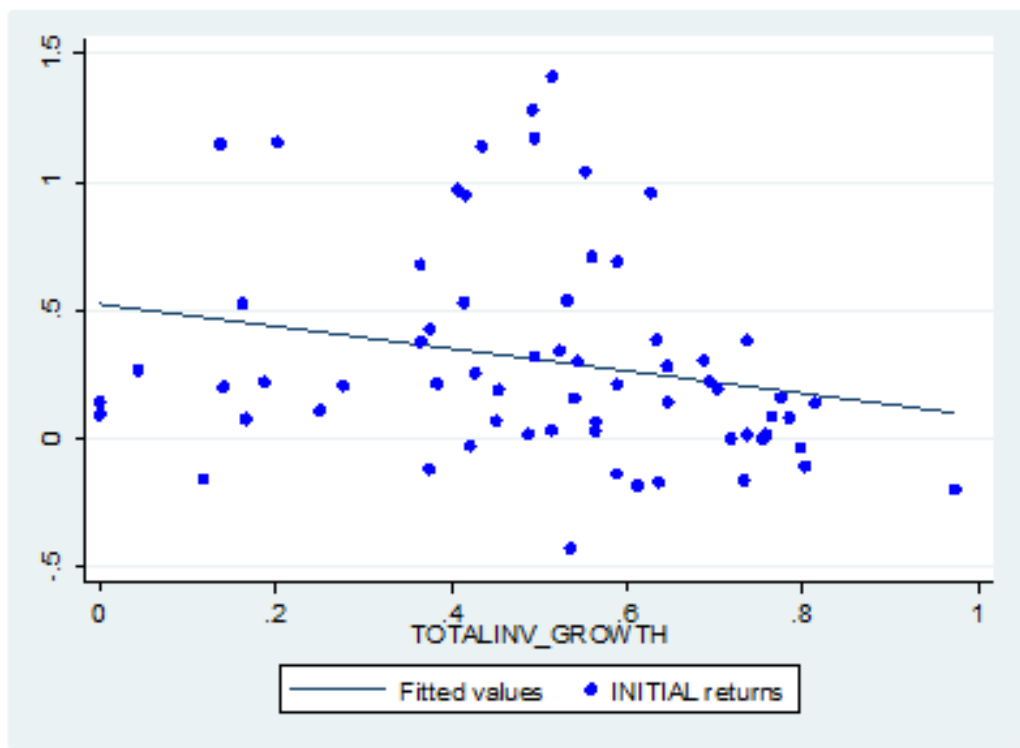

Figure 1: Scatter plot between initial returns and total percentage of IPO proceeds for investment purpose.

\section{Results}

Independent t-test is conducted on the cross-companies to determine if there were differences on issuing IPOs during the MCO or investing in the hi-tech companies or Shariah companies are more lucrative. The companies issued IPO during the MCO are grouped as dummy variables " 1 " or else " 0 " otherwise. The hi-tech companies also indicated " 1 " or none as " 0 ". As shown in Table 5, two t-tests were run and both groups have significant differences as their $p$-value is statistically failed to accept the Ho with confidence level lower than 0.05 percent. The result shows that issuing IPOs during MCO are much more lucrative to the investors by 61 percent as compared to the pre-MCO period. Besides, the result also shows that companies offering IPOs in the hi-tech industry had statistically significant differences by more than 65 percent. In addition to this, the study test on the significance of Shariah companies on the initial returns, but the result shows no actual difference. 
MANAGEMENT SCIENCES

Vol. 11, No. 3, 2021, E-ISSN: 2225-8329 @ 2021 HRMARS

Table 5: T-Test result

\begin{tabular}{|l|l|l|l|l|l|l|}
\hline & \multicolumn{2}{l|}{ MCO } & Hi-Tech & \multicolumn{2}{l|}{ Shariah Compliance } \\
\hline Group & Obs & Mean & Obs & Mean & Obs & Mean \\
\hline 0 & 51 & 0.2212304 & 58 & 0.2633319 & 12 & 0.4130813 \\
\hline 1 & 15 & 0.6131809 & 7 & 0.6562905 & 53 & 0.2813265 \\
\hline P-value & 0.0014 & 0.0174 & & 0.3274 & \\
\hline
\end{tabular}

Four OLS regression-static panel analyses are analysed on the sample companies as shown in the Table 6 column (1-4). The basic test to investigate the relationship of IPO intended proceeds and initial returns as shown in column (1). The regression is extended if there is any significant relationship during MCO and effect of hi-tech companies and Shariah compliance status towards initial return (as shown in column 2-4 respectively). The results show that INVGR and DEBTRPYN are significantly has negative influence on the companies' initial returns. The reason is mainly because most of the companies invested about 60 percent on average of their proceeds for investment and growth purposes reported negative initial returns. In contrast, the companies who invested their proceeds lower than 50 percent for the same purposes have positive initial returns. The scenario explained the inverse relationship as depicted in Figure 1 . Hence, the results are contrary to the fundamental theory and past studies. Possible explanation for this scenario is under subscription of the IPO by retail investors and cold timing of issuance.

The results of DEBTRPYN are constantly negative and statistically significant influence on the initial returns throughout all specifications from column 1 to 4 . The study is consistent with the Leone et. al. (2007) and McGuinness (2019) as the companies utilise their intended proceeds for debt repayment is not seen as a signal of projected cash flows and may be a negative indicator of future investment prospects. (Ahmad-Zaluki \& Badru, 2020).

On the other hand, the initial returns are influenced by structural break during MCO. During the MCO period, most of the companies issuing IPOs has positive and statistically significant initial returns. By looking at our data, about 86 percent equivalent to 12 companies who were offering their IPO were under-priced and recorded positive returns. Besides, the study further analyses the effect of the hi-tech industry and Shariah compliance status on the initial returns. The results show that the hi-tech industry reported to has positively significant in influencing the initial returns. Consistent with the prior studies as highlighted in Beatty \& Ritter (1986); Chung et al. (2005) and Leone et al. (2007), the evolution of the digitalization era contributes to the emergence of modern technology. When compared to non-tech IPOs, market news concerning high-tech IPOs grabs investors' attention more readily (Gao \& Hou, 2019). In contrast, the companies with Shariah compliance have no statistically significant relationship with initial returns. This may indicate that investors perceive Shariah status does not contain information for investment decisions. This result is in parallel with (Abdul Rahim \& Che Embi 2013; Abdul Rahim \& Yong, 2010). 
Table 6: Main Results

\begin{tabular}{lllll}
\hline & $(1)$ & $(2)$ & $(3)$ & $(4)$ \\
& COL1 & COL2 & COL3 & COL4 \\
\hline INVGR & $-1.199^{* * *}$ & $-0.977^{* *}$ & $-0.805^{* *}$ & $-0.806^{*}$ \\
& $(-2.879)$ & $(-2.624)$ & $(-2.034)$ & $(-1.983)$ \\
WCAP & $-0.007^{*}$ & -0.005 & -0.003 & -0.003 \\
& $(-1.729)$ & $(-1.453)$ & $(-0.994)$ & $(-0.974)$ \\
DEBTRPYN & $-0.972^{* *}$ & $-0.870^{* *}$ & $-0.774^{*}$ & $-0.742^{*}$ \\
& $(-2.156)$ & $(-2.057)$ & $(-1.944)$ & $(-1.841)$ \\
MCO & & $0.349 * *$ & $0.427^{* * *}$ & $0.407^{* * *}$ \\
& & $(2.416)$ & $(2.959)$ & $(2.846)$ \\
HTECH & & & $0.489^{* * *}$ & $0.501^{* * *}$ \\
& & & $(2.945)$ & $(2.972)$ \\
SHARH & & & & -0.085 \\
& & & & $(-0.680)$ \\
Intercept & $1.228^{* * *}$ & $0.993^{* * *}$ & $0.775^{* *}$ & $0.841^{* *}$ \\
& $(3.240)$ & $(2.879)$ & $(2.219)$ & $(2.182)$ \\
\hline Adj.R2 & 0.06 & 0.16 & 0.29 & 0.28 \\
$\mathrm{~N}$ & 65 & 65 & 65 & 65 \\
F-stat & 2.994 & 4.559 & 5.274 & 4.423 \\
\hline
\end{tabular}

Obs = number of observations

$t$ statistics in parentheses of confidence level $* p<0.10,{ }^{* *} p<0.05, * * * p<0.01$

\section{Robustness Results}

The study further regresses the analysis by different components of the total investment growth - PREINV. The finding of PREINV and DEBTRPYN remain consistent as shown in the Table 7 of column 2. Also, the results remain robust for the initial returns during $\mathrm{MCO}$ and the hi-tech companies.

Table 7: PREINV

\begin{tabular}{llll}
\hline & $(1)$ & $(2)$ & $(3)$ \\
& COL1 & COL2 & COL3 \\
\hline PREINV & -1.013 & $-1.084^{*}$ & -0.645 \\
WCAP & $(-1.739)$ & $(-1.781)$ & $(-1.037)$ \\
& -0.003 & -0.005 & 0.002 \\
DEBTRPYN & $(-0.447)$ & $(-0.699)$ & $(0.248)$ \\
& -1.189 & $-1.207^{*}$ & -0.633 \\
MCO & $(-1.440)$ & $(-2.081)$ & $(-0.926)$ \\
& & 0.579 & $0.728^{*}$ \\
HTECH & & $(1.668)$ & $(1.819)$ \\
& & & $0.698^{* *}$ \\
Intercept & & & $(2.873)$ \\
& $1.119 * *$ & $1.098^{* * *}$ & 0.477 \\
Adj.R2 & $(2.454)$ & $(3.040)$ & $(0.984)$ \\
N & -0.07 & 0.07 & 0.36 \\
F-stat & 19 & 19 & 19 \\
\hline
\end{tabular}

$t$ statistics in parentheses

${ }^{*} \mathrm{p}<0.10,{ }^{* *} \mathrm{p}<0.05,{ }^{* * *} \mathrm{p}<0.01$ 
MANAGEMENT SCIENCES

Vol. 11, No. 3, 2021, E-ISSN: 2225-8329 @ 2021 HRMARS

To summarize our findings, the initial returns are influenced negatively by the INVGR and DEBTRPYN. Surprisingly, our finding on the use of proceeds for INVGR is contrary to the previous studies which became part of a new important contribution to the literature.

\section{Conclusion and Recommendation}

The study aims to investigate whether information on the intended use of IPO proceeds has an impact on IPO initial return especially during the pandemic. In general, the under-pricing (positive and significant initial return) phenomenon still occurred during MCO. This supports $\mathrm{H} 1$ where MCO has an implication on IPO initial return. $\mathrm{H} 2$ is also supported as our empirical finding shows correlation between intended use of proceeds with IPO initial return. However, our findings show that INVGR and DEBTRPYN have a negative significant relationship with initial returns. The first is contrary to the previous literature and the latter is consistent with other empirical findings. The higher a firm proposes intended use of proceeds for investment purpose and debt repayment, the more it will contribute to negative initial return. Furthermore, our finding on IPO for high-tech companies is positively correlated with initial returns thus supporting hypothesis $H 3$. Nonetheless, Shariah compliance firms do not contribute to distinctive results eventually $\mathrm{H} 4$ is rejected.

The implication of this study can be important for businesses people to plan to get their companies go public during times of significant uncertainty, especially during the pandemic Covid-19. Our findings are particularly relevant for policymakers to understand the negative spill over effects on the economy, as well as for investors looking for investment opportunity in IPOs amid market stress. It also provides insight to capital market authorities to improve the requirement for prospectus disclosure to enhance quality, adequacy, and reliability of the information. Besides, our findings suggest new contributions to the literature.

The limitation of this research is from the use of limited sample size due to only few firms successfully listed during pandemic time. The study also excludes other contributing factors that may influence the investors' reaction on the first day of listing of such IPOs such as market volatility, other firms' characteristics, firms' financial ratio and material or immaterial corporate announcements prior to the listing day. This limitation creates avenues for future research by examining such factors and their relationship to IPOs' return. Further investigation on the short and long-term firm's operating profit post IPO issuance will be an interesting topic to be explored too. It can help to explain if there is any relationship between pre-issuance IPO intended use of proceeds and its future operating performance. This study can also be expanded to confirm whether the funds raised during IPO are used for the intended purpose by focusing on the post-pandemic samples.

\section{Corresponding Author}

Siti Azrina Adanan

Affiliation: Faculty of Accountancy, Universiti Teknologi MARA, KM26, Jalan Lendu, 78000 Alor Gajah Melaka, Malaysia.

Email: azrina@uitm.edu.my

\section{Acknowledgment}

The authors would like to extend their gratitude to Universiti Teknologi MARA, Melaka, for 
MANAGEMENT SCIENCES

Vol. 11, No. 3, 2021, E-ISSN: 2225-8329 @ 2021 HRMARS

funding this research through internal research grant 600-TNCPI 5/3/DDN (04) (031/2021).

\section{References}

Abdul Rahim, R., \& Che Embi, N. A. (2013). Initial returns of Shariah versus non-Shariah IPOs: Are there any differences? Jurnal Pengurusan UKM Journal of Management. DOI:10.17576/PENGURUSAN-2013-39-04

Abdul Rahim, R., \& Yong, O. (2008). Initials Return of Shariah-Compliant IPO in Malaysia. Capital Market Reviews, 16(2), 39-52.

Abdul Rahim, R., \& Yong, O. (2010). Initial returns of Malaysian IPOs and Shari'a-compliant status. Journal of Islamic Accounting and Business Research, 1(1), 60-74.

Abdul Rahman, S. S., \& Che-Yahya, N. (2019). Initial and long-term performance of IPOs. Does growth opportunity of issuing firm matter? Business and Economic Horizons, 15(2), 276-291.

Ahmad-Zaluki, N. A., \& Kect, L. B. (2020). Intended use of IPO proceeds and initial returns. Journal of Financial Reporting and Accounting.

Ahmad-Zaluki, N. A., \& Badru, B. O. (2012). The Investment Performance of MESDAQ Market Initial Public Offerings (IPOSs). Asian Academy Of Management Journal Of Accounting And Finance, 8(1), 1-23.

Ammer, M. A., \& Ahmad-Zaluki, N. A. (2016). The effect of underwriter's market share, spread and management earnings forecasts bias and accuracy on underpricing of Malaysian IPOs. International Journal of Managerial Finance, 12(3), 351-371.

Amor, S. B., \& Kooli, M. (2016). Intended use of proceeds and post-IPO performance. The Quarterly Review of Economics and Finance, 65, 168-181.

Andriansyah, A., \& Messinis, G. (2016). Intended use of IPO proceeds and firm performance: A quantile regression approach $\boldsymbol{i}$. Pacific-Basin Finance Journal, 36, 14-30.

Autore, D. M., Bray, D. E., \& Peterson, D. R. (2009). Intended use of proceeds and the longrun performance of seasoned equity issuers. Journal of Corporate Finance, 15(3), 358367.

Baig, A. S., \& Chen, M. (2021). Did the COVID-19 pandemic (really) positively impact the IPO Market? An Analysis of information uncertainty. Finance Research Letters. https://doi.org/10.1016/j.frl.2021.102372

Beatty, R., \& Ritter, J. (1986). Investment Banking, Reputation, and The Underpricing of Initial Public Offerings. Journal of Financial Economics, 15, 213-232.

Bhat, R. B., \& Suresh, V.N. (2020). Inter-linkages and performance of Asian stock markets amidst COVID 2019. International Journal of Financial Engineering, 7(3).

Chung, K. H., Li, M., \& Yu, L. (2005). Assets in Place, Growth Opportunities, and IPO Returns. Financial Management Association, 34(3), 65-88.

Gao, S., \& Hou, T. C.-T. (2019). An Empirical Examination of IPO Underpricing Between Hightechnology and Non-high-technology Firms in Taiwan. Journal of Emerging Market Finance, 18(1), 23-51.

Kuswanto, R. (2021). IPO Stock Performance amidst the COVID-19 Pandemic: Has It been Undervalued? Jurnal Dinamika Akuntansi dan Bisnis, 8(1), 105-116.

Leone, A. J., Rock, S., \& Willenborg, M. (2007). Disclosure of Intended Use of Proceeds and Underpricing in Initial Public Offerings. Journal of Accounting Research, 45(1), 111153.

Mazumder, S., \& Saha, P. (2021). COVID-19: Fear of pandemic and short-term IPO performance. Finance Research Letters, 1-10. 
MANAGEMENT SCIENCES

Vol. 11, No. 3, 2021, E-ISSN: 2225-8329 ๔ 2021 HRMARS

McGilvery, A., Paff, R., \& Pathan, S. (2012). Competitive valuation effects of Australian IPOs. International Review of Financial Analysis, 24, 74-83.

McGuinness, P. B. (2019). Risk factor and use of proceeds declarations and their effects on IPO subscription, price 'fixings', liquidity and after-market returns. The European Journal of Finance, 25(12), 1122-1146.

Mehmood, W., Mohd-Rashid, R., Tajuddin, A. H., \& Saleem, H. M. N. (2021). Shariahcompliance and IPO underpricing: evidence from Pakistan Stock Exchange. International Journal of Islamic and Middle Eastern Finance and Management. https://doi.org/10.1108/IMEFM-06-2020-0271

Rahman, M. T., Hossain, S. Z., Haque, M. A., \& Ashik, M. A. H. (2021). Exploration of IPO motives, oversubscription and flotation costs: Evidence from Bangladesh. International Journal of Management, Accounting, and Economics, 7(12), 708-725.

Rathnayake, D. N., Louembé, P. A., \& Kassi, D. F. (2019). Are IPOs underpriced or overpriced? Evidence from an emerging market. Research in International Business and Finance, 50, 171-190.

Siew, W. L., \& Sundarasen, S. D. (2015). IPO Initial Returns and Volatility: A Study in Emerging Market. International Journal of Business and Finance Research, 9(3), 71-82.

Tajuddin, A. H., Rashid, M. R., Hwei Khaw, K. L., \& Che Yahya, N. (2019). Shariah-compliant status and investors' demand for IPOs: The effects of information asymmetry. International Journal of Islamic and Middle Eastern Finance and Management, 12(4), 489-508.

Yaakub, N., \& Sherif, M. (2019). Performance of initial public offerings (IPOs): the case of Shariah-compliant companies. Islamic Economic Studies, 27-1(1), 65-76. https://doi.org/10.1108/IES-06-2019-0012

Yazdani, L., \& Aris, S. (2015). An Assessment of the Performance of Initial Public Offering (IPOs) in Malaysia. Research Journal of Finance and Accounting, 6(3), 1-4. 